\title{
Short selling and stock price crash risk
}

\author{
Jay M. Chung \\ School of Finance, College of Business Administration, Soongsil University, \\ Seoul, Republic of Korea, and \\ Shu-Feng Wang \\ College of Business Administration, Ajou University, Suwon, Republic of Korea
}

Short selling and stock price

\section{Received 6 April 2020 Revised 11 May 2020 18 May 2020 Accepted 18 May 2020}

\begin{abstract}
This paper aims to investigate short selling and stock price crash risk. The authors find that short selling is positively associated with one-month-ahead stock price crash risk, consistent with the literature showing that short sellers are informed traders. The authors attribute this prediction ability to the information short sellers receive from foreign investors with high levels of ownership in a firm. The results shed light on policy issues regarding short selling regulation.
\end{abstract}

Keywords Foreign ownership, Short selling, Crash risk

Paper type Research paper

\section{Introduction}

Prior studies show that short sellers are considered well-informed, sophisticated traders (Diamond and Verrecchia, 1987; Asquith and Meulbroek, 1995; Asquith, Pathak and Ritter, 2005; Desai et al., 2006; Boehmer et al., 2008; Diether et al., 2009). They show that the shorting volume increases before the dates of such events as earnings announcements and analyst downgrades (Christophe et al., 2004, 2010). In this paper, we attempt to find evidence on potential sources of information used by short sellers, especially foreign short sellers in an emerging market. There has been much debate on the information advantages of foreign investors in overseas markets. Froot et al. (2001) and Froot and Ramadorai (2008) show that foreign investors are informed and Seasholes (2004) investigates foreign investors' informational advantage in an emerging market, finding that foreign investors perform better than domestic investors in large and well-known firms in the equity market. While Brennan and Cao (1997), Grinblatt and Keloharju (2000) and Griffin et al. (2007) report the opposite finding. They show that foreign investors are disadvantage in information relative to domestic investors, therefore, they use momentum trading strategy. Dvořák (2005) and Choe et al. (2005) investigate informational advantage of foreign investors and find that domestic investor earn higher profit in Indonesian and Korean stock market, respectively.

(C) Jay M. Chung and Shu-Feng Wang. Published in Journal of Derivatives and Quantitative Studies: 선물연구. Published by Emerald Publishing Limited. This article is published under the Creative Commons Attribution (CC BY 4.0) licence. Anyone may reproduce, distribute, translate and create derivative works of this article (for both commercial and non-commercial purposes), subject to full attribution to the original publication and authors. The full terms of this licence may be seen at http:// creativecommons.org/licences/by/4.0/legalcode

Shu-Feng Wang gratefully acknowledges financial support from the new faculty funding of Ajou University.

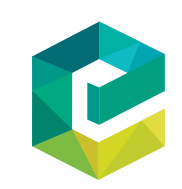

Journal of Derivatives and Quantitative Studies: 서물 연구 Vol. 28 No. 2,2020 Vol. 28 No. 2,2020

Emerald Publishing Limited p-ISSN: $1229-988 \mathrm{X}$ e-ISSN: 2713-6647 DOI 10.1108/JDQS-04-2020-0005 
JDQS 28,2

We investigate whether foreign short sellers, which are known as informed traders, in an emerging market are able to predict stock price crash and their sources of information. We focus on the Korean stock market because in 1997 legal limitations on foreign investor ownership were fully abolished, allowing foreign investors to actively sell short under less binding regulations [1]. Wang and Lee (2015) show that about $80 \%-90 \%$ of the daily total shorted volume in Korea is due to foreign investors, whereas only $10 \%-20 \%$ of the total shorted volume is due to individual and domestic institutional investors, suggesting that foreign investors are the major player in the short selling market [2].

Callen and Fang (2015) show that bad news hoarding leads to stock price crash risk and that short sellers are skilled in identifying such bad news in the USA. In this paper, we first examine whether short sellers predict stock price crash and then identify the source of their information. One possible source of information is tips received from foreign investors with high shares of ownership in a firm. We hypothesize that short sellers shorting a stock with a high level of foreign ownership are more likely to predict stock price crash. Although we do not have direct evidence of a "tipping" behavior link, our empirical evidence result leans toward the tipping trade.

We contribute to the literature by showing that short sellers identify firm bad news and that this news is provided by other foreign investors in the firm (tipping trade). Few papers investigate short sellers' information sources and some find that short sellers receive analyst downgrade information from brokerage firms (Christophe et al., 2010). Other papers show that short sellers have superior information processing skills (Engelberg et al., 2012). We add evidence on how informed short sellers in an emerging market obtain information. We find that short trading in the Korean stock market is not as active as in the USA market. Over $50 \%$ of stock-day observations have no shorting flow, and about $3 \%$ of total firms listed on the Korea Composite Stock Price Index (KOSPI) market have no shorted shares over the sample period. Moreover, we find that only $11 \%$ of total firms exhibit a level of relative short selling activity (relss) above $5 \%$, where relative short selling activity (relss) is defined as the number of shorted shares divided by the number of traded shares. We find average relss to be $3.6 \%$ after screening out stocks with small short sale volumes. Compared to the USA, with relss of $24 \%$ and $31 \%$ on the New York stock exchange (NYSE) and Nasdaq, respectively, short selling in the Korean stock market focuses on only a few firms.

We also find that short sellers are able to predict one-month-ahead stock price crash. This result is consistent with Callen and Fang (2015), the difference being that they use one-yearahead crash risk measures, whereas we use one-month-ahead measures. We use one-monthahead crash risk measures because, given the high cost of long-term investment, short sellers prefer short-term investment (Morck et al., 1990). The relative short selling activity and one-month-ahead stock price crash measures are positive and significant, suggesting that short sellers predict stock price crash. We also provide robustness tests to confirm that our results are not driven by the 2008 global financial crisis or short-term crash risk measures. Finally, we investigate short sellers' possible sources of information. We separate the sample into two subsamples based on firm foreign ownership. We find the ability to predict short selling only in stocks with high levels of foreign ownership, suggesting that short sellers receive firm bad news from foreign investors with high shares of ownership in those firms.

Our findings shed light on important policy issues regarding short selling regulation. We provide evidence that tipping could be common in short selling trade. Thus, our paper calls into question the fairness of certain investors participating in short selling trade. 
The remainder of the paper is organized as follows. Section 2 describes the data and sample, as well as the construction of the measures. Section 3 presents the empirical results and robustness tests. Section 4 provides evidence on the source of short sellers' information. The paper concludes in Section 5.

\section{Data and sample}

\subsection{Sample construction}

We obtain data on daily stock returns, daily short selling volumes, market capitalization, daily trading volumes and financial statements for stocks listed in the KOSPI market from January 1, 2006 to December 12, 2018, from FnDataGuide, one of the biggest data vendors in Korea. We exclude those stocks with fewer than 250 trading days over the sample period. We also drop observations missing monthly stock returns, trading volumes and short selling volumes. We further drop stock-year observations if the book-to-market ratio, leverage ratio or return on assets $(R O A)$ is not available that year. Following Diether et al., (2009), we measure the monthly relative short selling activity of stock $i$ in month $t$, denoted $r e l s s_{\mathrm{i}, \mathrm{t}}$, as the average daily ratio of the shorted share to the trading volume within the month:

$$
\text { relss }_{i, t}=\operatorname{Avg}\left[\frac{\# \text { shorted }_{\text {share }}, d}{\# \text { traded } \text { share }_{i, d}}\right]
$$

Wang and Lee (2015) show that relss quite low in Korea compared to the USA, 78\% of their stock-day observations have relss equal to zero. To avoid potential confounding effects on the empirical results, especially for monthly relss, we first examine the sample stock-day observations of relss. Table 1 shows the distribution of stock-day observations of relss for 900 stocks, with 3,701,075 stock-day observations in the KOSPI market.

Panel A of Table 1 shows the stock-day observations of relss. A total of $53.79 \%$ of stockday observations have no short selling activity and $40.96 \%$ of stock-day observations have relss less than $10 \%$. The Column 1 in Panel B shows the average number of firms in each range of relss shown. For each stock, we calculate the average daily relss over the sample period and group them accordingly. We see that over 3\% of firms' relss are zero and that about $50 \%$ of firms' relss are less than $1 \%$. In Panel C, we show the portion of nonzero short selling that is we calculate the number of nonzero relss stock-day observations, divided by the total number of days for each stock over the sample period. The result shows that $55.2 \%$ of firms have an average nonzero relss ratio of less than $50 \%$, suggesting that use of the full sample to perform analyzes could result in bias in the empirical analysis.

Given the rarity of short selling in the Korean stock market, we restrict our sample to stocks with a nonzero relss ratio above $50 \%$ over the sample period. After all screening, our final sample consists of 400 firms with 45,228 stock-month observations.

\subsection{Stock price crash risk}

To examine the relation between stock price crash risk and short selling activity, we need to construct stock price crash risk. Following Chen et al. (2001), we construct two stock price crash risk measures for each firm in each month. The first measure is Skewness, which is defined as the negative coefficient of the skewness of firm-specific daily returns. Specifically, we first estimate firm-specific daily returns from the regression of daily stock returns on lead and lag terms for the market and industry index returns for each firm each month. We include lead and lag terms for the market and industry indexes for allow nonsynchronous trading. The specification is as follows: 
JDQS

28,2

Range

No. of stock-day obs.

$(\%)$

Panel A: Stock-day observations

relss $=0 \%$

$0 \%<$ relss $\leq 10 \%$

$0 \%<$ relss $\leq 1 \%$

66

$1 \%<$ relss $\leq 2 \%$

$2 \%<$ relss $\leq 3 \%$

$3 \%<$ relss $\leq 4 \%$

$4 \%<$ relss $\leq 5 \%$

$5 \%<$ relss $\leq 6 \%$

$6 \%<$ relss $\leq 7 \%$

$7 \%<$ relss $\leq 8 \%$

$8 \%<$ relss $\leq 9 \%$

$9 \%<$ relss $\leq 10 \%$

$10 \%<$ relss $\leq 20 \%$

$20 \%<$ relss $\leq 30 \%$

relss $>30 \%$

Total

$1,412,399$

$1,075,376$

493,377

167,446

108,737

78,692

60,655

47,723

38,495

31,424

26,384

22,443

104,281

25,474

8,169

3,701,075

53.79

40.96

18.79

6.38

4.14

3.00

2.31

1.82

1.47

1.20

1.00

0.85

3.97

0.97

0.31

Panel B: Stock observations

Range

No. of stocks

$(\%)$

relss $=0 \%$

$0 \%<$ relss $\leq 1 \%$

$1 \%<$ relss $\leq 2 \%$

$2 \%<$ relss $\leq 3 \%$

$3 \%<$ relss $\leq 4 \%$

$4 \%<$ relss $\leq 5 \%$

relss $>5 \%$

29

428

143

3.22

89

47.56

66

15.89

41

9.89

7.33

104

4.56

Total

900

11.56

100.00

Panel C: Portion of non-zero short selling

$\begin{array}{lc}\begin{array}{l}\text { Range } \\ \text { relss }=0 \%\end{array} & \text { Non-zero } \text { relss ratio } \\ 0 \%<\text { relss } \leq 10 \% & 0.00 \\ 10 \%<\text { relss } \leq 20 \% & 4.99 \\ 20 \%<\text { relss } \leq 30 \% & 15.09 \\ 30 \%<\text { relss } \leq 40 \% & 25.79 \\ 40 \%<\text { relss } \leq 50 \% & 35.06 \\ 50 \%<\text { relss } \leq 60 \% & 44.19 \\ 60 \%<\text { relss } \leq 70 \% & 55.06 \\ 70 \%<\text { relss } \leq 80 \% & 65.48 \\ 80 \%<\text { relss } \leq 90 \% & 75.01 \\ \text { relss }>90 \% & 84.59 \\ \text { Total } & 95.68\end{array}$

No. of stocks

$(\%)$

29

3.22

84

9.33

$82 \quad 9.11$

$10 \%<$ relss $\leq 20 \%$

9.11
10.11

91

11.56

104

11.89

Table 1.

Distribution of average relative

Total

107

8.67

9.33

$\begin{array}{rr}84 & 9.33 \\ 67 & 7.44 \\ 92 & 9.11 \\ 92 & 10.22\end{array}$

$\begin{array}{rr}84 & 9.33 \\ 67 & 7.44 \\ 92 & 9.11 \\ 92 & 10.22\end{array}$

short selling

$$
\begin{aligned}
R_{i, t}= & \alpha_{i}+\beta_{1, j} R_{m, t-1}+\beta_{2, j} R_{i n d, t-1}+\beta_{3, j} R_{m, t}+\beta_{4, j} R_{i n d, t}+\beta_{5, j} R_{m, t+1}+\beta_{6, j} R_{i n d, t+1} \\
& +\varepsilon_{i, t}
\end{aligned}
$$

where $R_{i, t}$ is the return on stock $i$ on day $t, R_{m, t}$ is the return on the KOSPI on day $t$ and $R_{i n d, t}$ is the value-weighted average individual stock return for each industry ind on day $t$. The industry classification is that of the Korea stock exchange. Specifically, we estimate equation (1) for a given stock in a given month and use the logarithmic value of one plus the 
residual $\left(1+{ }_{i, t}\right)$ as the firm-specific daily return $\left(r_{i . t}\right)$. We then defined Skewness as the coefficient of the monthly skewness of firm-specific daily returns, as follows:

$$
\text { Skewness }_{i, t}=-\frac{\left(n(n-1)^{\frac{3}{2}} \sum r_{i, t}^{3}\right)}{\left((n-1)(n-2)\left(\sum r_{i, t}^{2}\right)^{\frac{3}{2}}\right)}
$$

Another stock price crash risk measure is Down-to-Up, which is the ratio of the standard deviation of down days, in terms of firm-specific daily returns, to the standard deviation of up days, as follows:

$$
\text { Down }- \text { to }-U p_{i, t}=\log \left\{\frac{\left(n_{\text {Down }}-1\right) \sum_{\text {Down }} r_{i, t}^{2}}{\left(n_{U p}-1\right) \sum_{U p} r_{i, t}^{2}}\right\}
$$

For both two stock price crash risk measures, we drop stock-month observations if a stock has fewer than 10 trading days in a given month.

\subsection{Control variables}

We use a set of control variables that potentially affect to our stock price crash risk measures. Following Chen et al. (2001), we use Daily ret, Kurtosis, Sigma, LnSize, Abnormal $t v, B / M$ ratio, $R O A$ and $L e v$ as control variables, where Daily ret (per cent) is the average stock's daily return in a given month; Kurtosis is the kurtosis of firm-specific daily returns in a given month; Sigma is the standard deviation of firm-specific daily returns in a given month; LnSize is stock capitalization, defined as the logarithm of the month-end stock price times the number of shares outstanding; Abnormal tv is the abnormal trading volume, defined as the difference between the current month $t v$ value and the previous month's, where $t v$ is share turnover, which is the ratio of the monthly volume of traded shares to the number of shares outstanding that month; $B / M$ ratio is the book-to-market ratio, which defined as the previous year-end book equity divided by the previous year-end market capitalization;. $R O A$ is the return on assets, defined as the previous fiscal year's net income divided by the previous fiscal year's total assets; and Lev is the leverage ratio, defined as the previous fiscal year's total liability scaled by the previous year's total assets.

\section{Empirical analysis}

\subsection{Descriptive statistics}

Table 2 presents summary statistics of the stock price crash risk measures and control variables.

The mean of relss is $3.622 \%$ in our sample, which is higher than the relss reported by Wang and Lee (2015). Wang and Lee using 50 stocks with the highest average relss from January 1, 2006 to May 31, 2010. Our mean relss is higher than theirs because short selling activity increased significantly since 2010. Figure 1 shows the relss of our sample. We see that relss increases from 2006 to 2008 and then experiences a big drop, which is the short selling ban during the financial crisis period [3]. After 2009, short selling activity increased significantly. However, overall, the relss in the Korean stock market are small compared to those in the USA market [4]. The mean values of the two stock price crash risk measures Skewness and Down-to-Up are -0.213 and -0.138 , respectively. This result is similar to that 


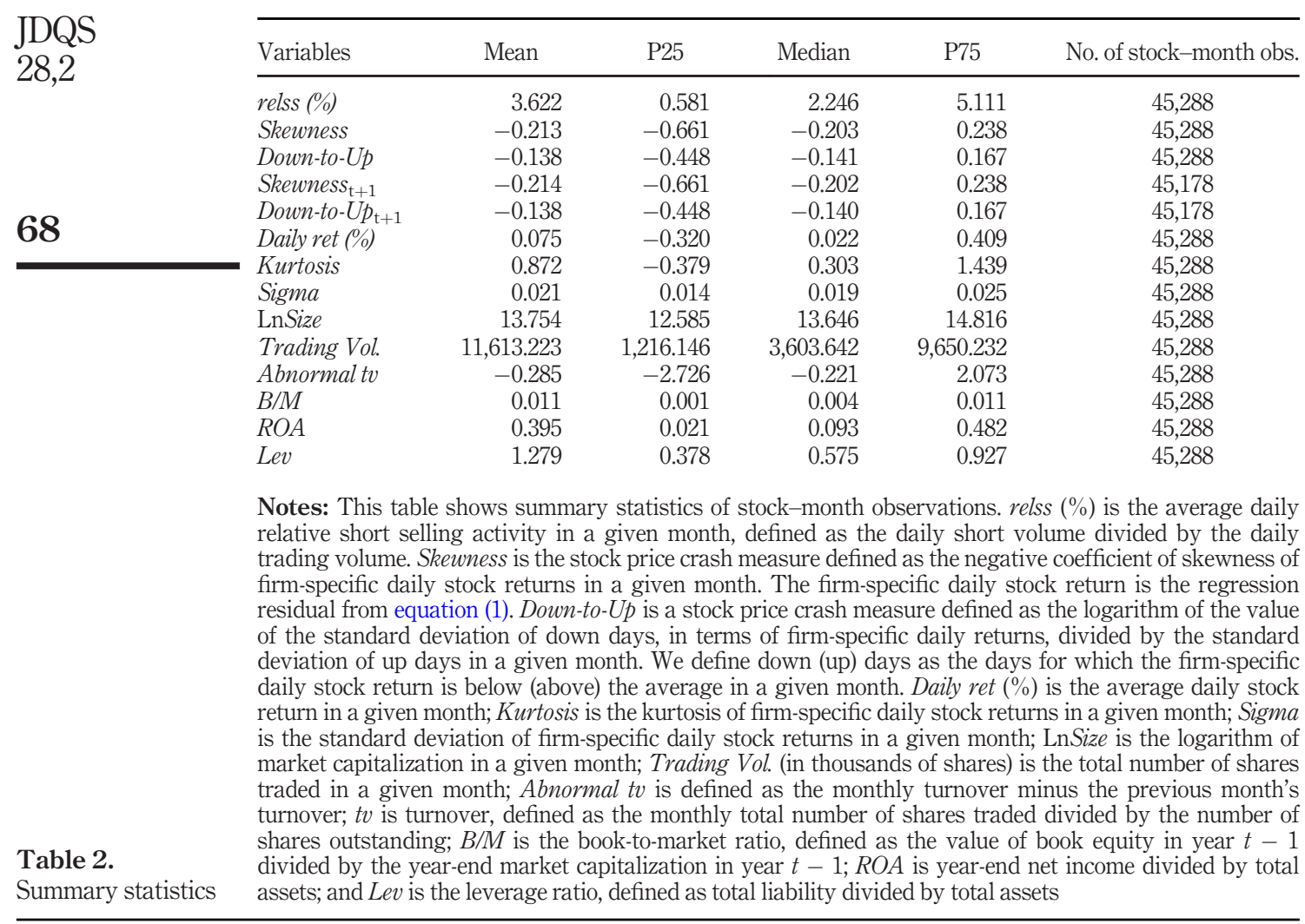

of Chen et al. (2001), who, using market-adjusted returns, find Skewness and Down-to-Up values of -0.262 and -0.190 , respectively.

\subsection{Portfolio analysis}

In this section, we determine whether short selling activities predict stock price crash. Given that short sellers are short-term investors (Morck et al., 1990; Wang et al., 2017), we use onemonth-ahead stock price crash risk in a portfolio analysis. Table 3 presents the results of univariate portfolio sort analysis. Specifically, for each month $t$, we first separate out the subsample of observations with nonzero relss values and then sort these into four groups based on their relss. We then report the time-series average of the cross-group means of Skewness and Down-to-Up in month $t+1$, with standard errors adjusted according to Newey and West (1987). The Column 1 in Table 3 shows the relss ranks for the groups Zero to High. The Column 2 shows the month $t+1$ Skewness values. We see that Skewness is monotonically increasing with relss. The difference between the High and Low groups is positive and significant at the $1 \%$ significance level. The Column 1 shows the results for the Down-to-Up measure, consistent with Skewness. The results in Table 3 are consistent with the work of Callen and Fang (2015), who find that short interest is positively associated with one-year-ahead stock price crash risk. Overall, our results are consistent with our hypothesis, in that short selling activities predict stock price crash. 


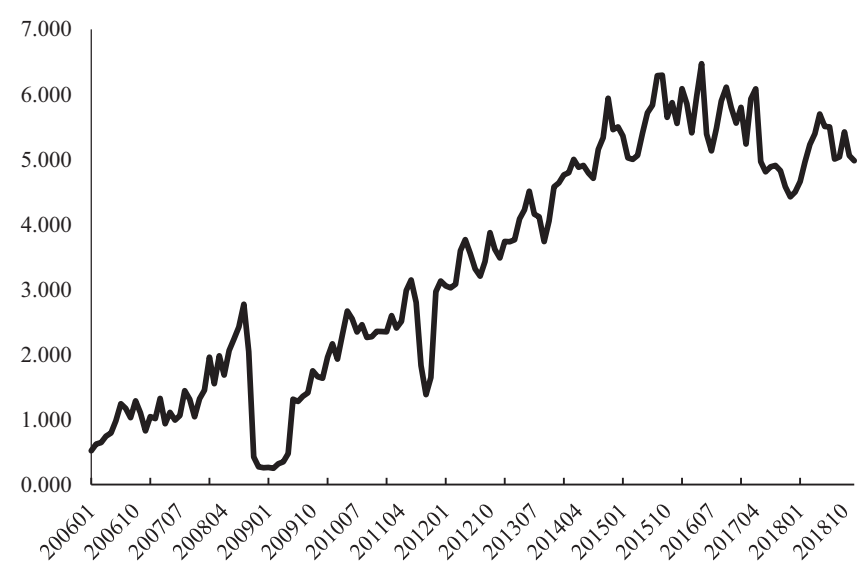

Notes: This figure shows the relative short selling activity (relss) for our 400 sample stocks. The variable relss (\%), relative short selling activity, is defined as the daily short volume divided by the daily trading volume. We average the daily relss for a given stock in a given month as the monthly relss and we report the crosssectional mean of relss
Short selling
and stock price

69

Figure 1.

Relative short selling activity for 400 stocks

\begin{tabular}{|c|c|c|}
\hline Rank by relss & Skewness $_{t+1}$ & Down-to- $U p_{t+1}$ \\
\hline $\begin{array}{l}0 \text { (Zero) } \\
1 \text { (Low) } \\
2 \\
3 \\
4 \text { (High) } \\
\text { High-Low }\end{array}$ & $\begin{array}{c}-0.192^{* * *}{ }^{* *}(-3.92) \\
-0.269^{* * *}(-17.75) \\
-0.222^{* * *}{ }^{*}(-15.17) \\
-0.179^{* * *}{ }^{*}(-12.44) \\
-0.164^{* * *}{ }^{*}(-11.02) \\
0.106^{* *}{ }_{(8.90)}\end{array}$ & $\begin{array}{c}-0.127^{* * *}{ }^{* *}(-5.42) \\
-0.170^{* * *}(-17.62) \\
-0.143^{* * *}(-15.81) \\
\left.-0.120^{* * *}{ }_{(-13.04)}\right) \\
-0.107^{* * *}(-11.52) \\
0.063^{* * *}{ }_{(8.24)}\end{array}$ \\
\hline
\end{tabular}

Notes: This table shows the stock price crash risk according to relss (\%). For month $t$, we first separate out the subsample for which relss is nonzero and then divide the nonzero relss sample into four groups based on relss. We report the time-series average of the cross-group mean of Skewness $S_{t+1}$ and Down-to-Up $p_{t+1}$. relss $(\%)$ is the average daily relative short selling activity in a given month, defined as the daily short volume divided by the daily trading volume. Skewness is the stock price crash measure defined as the negative coefficient of skewness of firm-specific daily stock returns in a given month. The firm-specific daily stock return is the regression residual from equation (1). Down-to-Up is the a stock price crash measure defined as the logarithm of the standard deviation of down days, in terms of firm-specific daily returns, divided by the standard deviation of up days in a given month. We define down (up) days as the days for which the firmspecific daily stock returns are below (above) the average in a given month. The $t$-statistics are in parentheses and standard errors are corrected by using the Newey-West procedure; ${ }^{* * *} ;{ }^{* *} ;$; indicate statistical significance at the $1 \%, 5 \%$ and $10 \%$ levels, respectively

Table 3.

One-way sort portfolio

\subsection{Regression analysis}

In the portfolio analysis, we show that the significantly positive relation between short selling activity and one-month-ahead stock price crash risk suggests that short sellers predict stock price crash. In this section, we perform a formal analysis to determine whether the predictive power of short selling remains strong after controlling for other stock 
JDQS
28,2

70

characteristics that are known to predict stock price crash (Chen et al. (2001)). Our monthly cross-sectional regression is as follows:

$$
\operatorname{Crash}_{i, t+1}=\alpha_{t}+\beta_{t} \text { relss }_{i, t}+\gamma_{t} X_{i, t}+\varepsilon_{i, t+1}
$$

where $\mathrm{Crash}_{i, t+1}$ denotes the two stock price crash risk measures of stock $i$ in month $t+1$ that is Skewness and Down-to-Up; relss $s_{i, t}$ is the relative short selling activity of stock $i$ in month $t$; and $X_{i, t}$ is a set of control variables for stock $i$ in month $t$. The control variables are the skewness of firm-specific daily returns (Skewness), the kurtosis of firm-specific daily returns (Kurtosis), the standard deviation of firm-specific daily returns (Sigma), the average stock daily return (Daily ret), the book-to market ratio $(B / M)$, the previous fiscal year's total liability scaled by total assets $(L e v)$, the previous fiscal year's net income scaled by total assets $(R O A)$, the logarithm of market capitalization (LnSize) and month $t$ 's share turnover minus the previous month's share turnover (Abnormal tv).

Table 4 shows the time-series average of the coefficients from the Fama and MacBeth (1973) cross-sectional regression of one-month-ahead stock crash risk on relss, controlling for other firm characteristics that potentially affect stock crash risk. The $t$-statistics are in parentheses and standard errors are adjusted by using the Newey and West (1987) method.

\begin{tabular}{lcc}
\hline Independent variables & Skewness $_{\mathrm{t}+1}$ & Down-to-Up $_{\mathrm{t}+1}$ \\
\hline relss & $0.0025^{*}(1.84)$ & $0.0019^{* *}(2.16)$ \\
Skewness & $0.0128^{* *}(2.37)$ & $0.0093^{* * *}(2.65)$ \\
Kurtosis & $0.0015(0.72)$ & $0.0013(1.18)$ \\
Sigma & $-0.0140^{* *}(-2.21)$ & $-0.0125^{* * *}(-3.22)$ \\
Daily ret & $0.0058^{(0.91)}$ & $0.0037(0.95)$ \\
B/M & $1.0979^{* * *}(3.71)$ & $0.7436^{* * *}(4.40)$ \\
Lev & $0.0011(0.54)$ & $0.0007(0.54)$ \\
ROA & $-0.0096^{*}(-1.70)$ & $-0.0056(-1.61)$ \\
LnSize & $0.0676^{* * *}(15.89)$ & $0.0392^{* * *}(15.83)$ \\
Abnormal tv & $0.0479^{* *}(2.04)$ & $0.0321^{* *}(2.07)$ \\
$R^{2}$ & 0.056 & 0.055 \\
Adj. $R^{2}$ & 0.021 & 0.020
\end{tabular}

Notes: This table reports the stock-level cross-sectional regression results of the predictability of short selling activity, using Fama and MacBeth (1973) methodology. The dependent variables are two stock price crash risk measures, Skewness and Down-to-Up, respectively. Skewness is the stock price crash measure defined as the negative coefficient of skewness of firm-specific daily stock returns in a given month, where the firm-specific daily stock return is the regression residual from equation (1). Down-to-Up is the other stock price crash measure, defined as the logarithm of the standard deviation down days, in terms of firmspecific daily returns, divided by the number of up days in a given month. We define down (up) days as the days with firm-specific daily stock returns below (above) the average in a given month. relss (\%) is the average daily relative short selling activity in a given month, defined as the daily short volume divided by the daily trading volume; Kurtosis is the kurtosis of firm-specific daily stock returns in a given month; Sigma is the standard deviation of firm-specific daily stock returns in a given month; Daily ret (\%) is the average daily stock return in a given month; $B / M$ is the book-to-market ratio, defined as the value of book equity in year $y-1$ divided by the year-end market capitalization in year $y-1$; Lev is the leverage ratio, defined as total liability divided by total assets; $R O A$ is year-end net income divided by total assets; LnSize is the logarithm of market capitalization in a given month; Abnormal tv is defined as monthly turnover minus the previous month's turnover; and $t v$ is turnover, defined as the monthly total number of shares

Table 4. Predictability of short selling traded divided by the number of shares outstanding. The intercepts are estimated but are not tabulated here. The $t$-statistics are in parentheses, and standard errors are corrected by using the Newey-West procedure; ${ }^{* *} ;{ }^{* *} ;{ }^{*}$ indicate statistical significance at the $1 \%, 5 \%$ and $10 \%$ levels, respectively 
The first specification shows the results for Skewness, while the second specification shows the results for Down-to-Up and the average coefficients of relss are 0.0025 and 0.0019 , respectively, significant at the $10 \%$ and $5 \%$ significance levels. These results are consistent with the prior literature where short sellers are informed traders (Boehmer et al., 2008; Boehmer and Wu, 2013; Christophe et al., 2010; Diether et al., 2009).

Overall, our results support our hypothesis, in that short sellers can predict stock price crash. In terms of the control variables, except for Kurtosis, Daily ret and Lev, the firm characteristic variables are consistent with the prior literature. For example, Abnormal tv is positive and highly significant for both equations, suggesting that, all else being equal, stocks that experience abnormally high turnover become more crash prone. Moreover, firm size is positively and significantly linked to one-month-ahead Skewness and Down-to-Up, suggesting that large firms tend to have negative skewness. The coefficients of $B / M$ are positive and significant, suggesting that value stocks are more crash prone. This result is inconsistent with Harvey and Siddique (2000), Chen et al. (2001) and Callen and Fang (2015), who find that growth stocks are more crash prone. One possible explanation for the positive relation between $B / M$ and negative skewness is investors' preference for positive skewness in stock returns. People are well known to prefer lottery stocks, which have highly rightskewed payoffs (Green and Hwang, 2012; Kahneman and Tversky, 1979) Relatedly, Zhang (2013) shows that investors' skewness-seeking behavior explains the difference in skewness across book-to-market portfolios and investors' preference for growth stocks. Zhang's results suggest that growth stocks are likely to be positively skewed.

\subsection{Robustness check}

We further perform a number of robustness checks. Table 5 shows the results. First, when the Financial Supervisory Service (FSS) in of Korea banned short selling for stocks listed on KOSPI and KOSDAQ from October 1, 2008, to May 31, 2009, it did not restrict investors whose purpose for selling short is to provide liquidity or to hedge underlying positions. We, therefore, exclude the short selling ban period to avoid any confounding effect. The results are show in Columns (1) and (2) of Table 5. The relss predicts the one-month-ahead stock price crash, with 0.0025 and 0.0019 and the t-values are 1.77 and 2.03 for Skewness and Down-to-Up, respectively.

Thus far, we have investigated the ability of relss to predict stock price crash one month ahead. We now check whether this ability to predict holds for longer horizons. In Columns (3) to (6) of Table 5, we replace one-month-ahead crash measures (Skewness and Down-to-Up) with average three-month and average six-month crash measures. We see that relss is positive and significant in all specifications, except when the average three-month Down-toUp measure is a dependent variable. The control variables in Table 5 are the same as in Table 4.

\section{Source of the predictability}

Our finding of the impact of relss on future stock price crash risk might not imply that short sellers are informed traders. In this section, we perform an analysis to show that the ability to predict of relss could depend on firm characteristics. Prior literature shows that short sellers earn profits through short selling trade because they have a superior ability to process public information. For example, Engelberg et al. (2012) show that short sellers make profits through the superiority of their information processing skills in the USA. Wang et al. (2017) also find similar results, where short sellers' profits in the Korean stock market are attributed to their information processing skills. On the other hand, Christophe et al. (2010) investigate short selling activity prior to analyst downgrades. They find that 
JDQS

28,2

72

Table 5.

Robustness tests

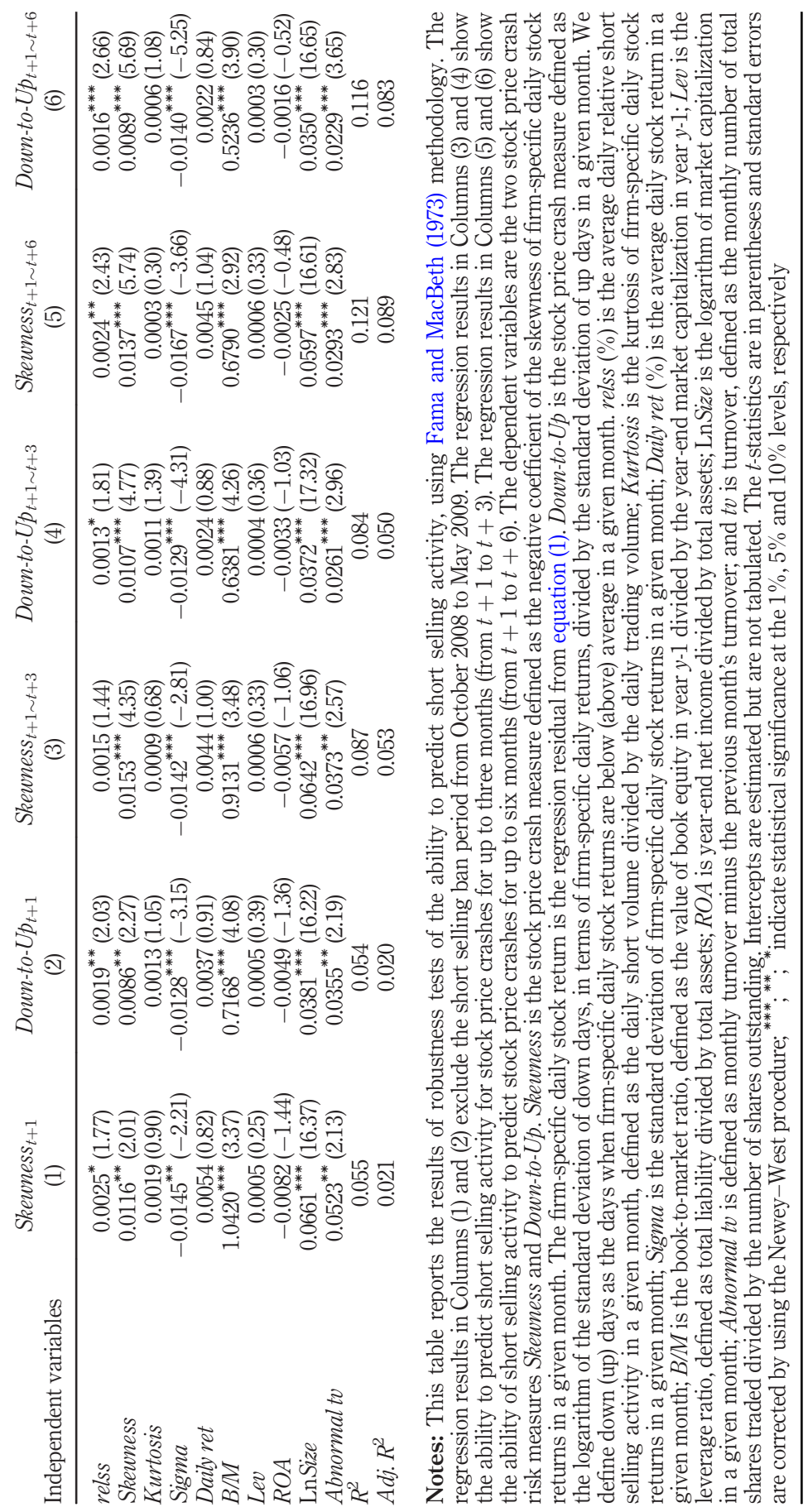


short sellers trade on information obtained from brokerage houses (i.e. tipping). Wang and Lee (2015) also show that about $80-90 \%$ of shares are shorted by foreign short sellers and individual investors and domestic investors account for the remaining 10-20\%. Based on the above literature, we hypothesize that the ability to predict of relss is more likely to be strong for those stocks with a high share of foreign ownership. Table 6 shows the results.

Specifically, we split the sample into two groups based on foreign ownership. We classify stocks whose level of foreign ownership is above (below) the cross-sectional average value as belonging to the high (low) foreign ownership group. Foreign ownership is measure by the number of shares held by foreign investors scaled by the total number of outstanding shares at the end of the month. We report the time-series average coefficients for Fama and MacBeth (1970) cross-sectional regression. As expected, relss is positive and significant only in the high group. Although we do not have specific data to examine the relation between short selling and foreign ownership in detail, our empirical evidence suggests that short sellers could obtain information on a firm from foreign investors with a high ownership share in that firm.

\begin{tabular}{lcccc}
\hline & \multicolumn{2}{c}{ Skewness $_{\mathrm{t}+1}$} & \multicolumn{2}{c}{ Down-to-Up $p_{\mathrm{t}+1}$} \\
Independent variables & Low & High & Low & High \\
\hline Relss & $-0.0031(-1.00)$ & $0.0040^{* *}(2.15)$ & $-0.0013(-0.64)$ & $0.0030^{* *}(2.28)$ \\
Skewness & $0.0213^{* * *}(2.62)$ & $-0.0009(-0.11)$ & $0.0144^{* * *}(2.89)$ & $0.0007(0.15)$ \\
Kurtosis & $0.0020(0.74)$ & $0.0022(0.62)$ & $0.0015(0.99)$ & $0.0017(0.74)$ \\
Sigma & $-0.0087(-1.38)$ & $-0.0277^{* * *}(-2.74)$ & $-0.0087^{* *}(-2.29)$ & $-0.0227^{* * *}(-3.43)$ \\
Daily ret & $0.0000(-0.01)$ & $0.0213(1.63)$ & $-0.0009(-0.24)$ & $0.0150^{*}(1.81)$ \\
B/M & $1.2690^{* * *}(4.23)$ & $0.3996(0.37)$ & $0.7864^{* * *}(4.82)$ & $0.4740(0.72)$ \\
Lev & $-0.0015(-0.53)$ & $0.0069^{*}(1.72)$ & $-0.0013(-0.79)$ & $0.0048^{* *}(2.06)$ \\
ROA & $-0.0085(-0.88)$ & $-0.0136(-1.55)$ & $-0.004(-0.74)$ & $-0.0081(-1.54)$ \\
LnSize & $0.0733^{* * *}(15.08)$ & $0.0495^{* * *}(7.38)$ & $0.0404^{* * *}(14.22)$ & $0.0299^{* * *}(7.72)$ \\
Abnormal tv & $0.0365(1.33)$ & $0.2090(1.53)$ & $0.0264(1.53)$ & $0.1177(1.44)$ \\
$R^{2}$ & 0.071 & 0.116 & 0.070 & 0.112 \\
Adj. $R^{2}$ & 0.014 & 0.021 & 0.014 & 0.017 \\
& & & &
\end{tabular}

Notes: This table shows the Fama and MacBeth (1973) regression results of the ability of short selling to predict one-month-ahead stock price crash, by foreign ownership. We split the sample into two groups, based on foreign ownership. If a stock's foreign ownership is above (below) the cross-sectional average, we classify it in the High (Low) group. The dependent variables are the two stock price crash risk measures, Skewness and Down-to-Up. Skewness is the stock price crash measure defined as the negative coefficient of the skewness of firm-specific daily stock returns in a given month. The firm-specific daily stock return is the regression residual from equation (1). Down-to-Up is the stock price crash measure defined as the logarithm of the standard deviation of down days, in terms of firm-specific daily returns, divided by the standard deviation of up days in a given month. We define down (up) days as the days with firm-specific daily stock returns below (above) the average in a given month. relss (\%) is the average daily relative short selling activity in a given month, defined as the daily short volume divided by the daily trading volume; Kurtosis is the kurtosis of firm-specific daily stock returns in a given month; Sigma is the standard deviation of firm-specific daily stock returns in a given month; Daily ret (\%) is the average daily stock return in a given month; $B / M$ is the book-to-market ratio, defined as the value of book equity in year $y-1$ divided by the year-end market capitalization in year $y$-1; Lev is the leverage ratio, defined as total liability divided by total assets; $R O A$ is year-end net income divided by total assets; LnSize is the logarithm of market capitalization in a given month; Abnormal tv is defined as monthly turnover minus the previous month's turnover; and $t v$ is turnover, defined as the monthly total number of shares traded divided by the number of shares outstanding. Intercepts are estimated but not tabulated. The $t$-statistics are in parentheses, and standard errors are corrected by using the Newey-West procedure; ${ }^{* * *} ;{ }^{* * *} ;$ *indicate statistical significance at the $1 \%, 5 \%$ and $10 \%$ levels, respectively

Short selling and stock price

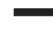


JDQS

28,2

\section{Conclusion}

This paper investigates short selling activity and future stock crash risk. Using relative short selling activity (relss) and the one-month-ahead negative skewness coefficient of daily stock returns, we find that short selling activity predicts future stock crash. The results are robust to both a portfolio analysis and a multivariate regression framework. Engelberg et al. (2012) find that short sellers have superior ability to analyze public information, while Christophe et al. (2010) find that short sellers receive information from brokerage houses, suggesting tipping. We also find results consistent with those of Christophe et al. (2010), in that short sellers receive stock price crash risk information from firms that have high levels of foreign ownership. As, in the Korean stock market, foreign short sellers account for $80 \%$ of the total number of shorted shares, we can infer that foreign traders are tipping. Our paper extends the literature on short sellers' or foreign investors' behavior in emerging markets by showing that the information of short sellers, especially foreign short sellers, is obtained not from the skilled stock analysis but, rather, from tips by foreign investors who have a high share of ownership in firms.

Our paper sheds light on the important issues regarding short selling policy making. Recently, many have been attempting to abolish or restrict short selling trade in the Korean stock market, arguing that current short selling-related policy favors domestic institutional investors and foreign investors in term of stock borrowing. We provide little evidence of potential collusion between short sellers and foreign investors, which could provide useful information to policymakers.

\section{Notes}

1. The Korean stock market introduced covered short selling to institutional investors in September 1997 and to foreign investors in July 1998.

2. As foreign short sellers are a big player in the Korean stock market, we use the daily shorting flow to proxy for foreign shorting flow. We also use the terms short sellers and foreign short sellers interchangeably.

3. The Financial Supervisory Service prohibited the short selling of all stocks listed on KOSPI and KOSDAQ from October 1, 2008, to May 31, 2009.

4. Diether et al. (2009) find relss of $24 \%$ and $31 \%$ for the NYSE and Nasdaq, respectively.

\section{References}

Asquith, P. and and Meulbroek, L. (1995), “An empirical investigation of short interest”, Working paper. Harvard Business School.

Asquith, P., Pathak, P.A. and Ritter, J.R. (2005), "Short interest, institutional ownership, and stock returns", Journal of Financial Economics, Vol. 78 No. 2, pp. 243-276.

Boehmer, E. and Wu, J. (2013), "Short selling and the price discovery process", Review of Financial Studies, Vol. 26 No. 2, pp. 287-322.

Boehmer, E., Jones, C.M. and Zhang, X. (2008), "Which shorts are informed?”, The Journal of Finance, Vol. 63 No. 2, pp. 491-527.

Brennan, M.J. and Cao, H.H. (1997), "International portfolio investment flows", The Journal of Finance, Vol. 52 No. 5, pp. 1851-1880.

Callen, J.L. and Fang, X. (2015), "Short interest and stock price crash risk", Journal of Banking and Finance, Vol. 60, pp. 181-194.

Chen, J., Hong, H. and Stein, J.C. (2001), "Forecasting crashes: trading volume, past returns, and conditional skewness in stock prices", Journal of Financial Economics, Vol. 61 No. 3, pp. 345-381. 
Choe, H., Kho, B.C. and Stulz, R.M. (2005), "Do domestic investors have an edge? The trading experience of foreign investors in Korea”, Review of Financial Studies, Vol. 18 No. 3, pp. 795-829.

Christophe, S.E., Ferri, M.G. and Angel, J.J. (2004), "Short-selling prior to earnings announcements", The Journal of Finance, Vol. 59 No. 4, pp. 1845-1876.

Christophe, S.E., Ferri, M.G. and Hsieh, J. (2010), "Informed trading before analyst downgrades: evidence from short sellers”, Journal of Financial Economics, Vol. 95 No. 1, pp. 85-106.

Diamond, D.W. and Verrecchia, R.E. (1987), "Constraints on short-selling and asset price adjustment to private information”, Journal of Financial Economics, Vol. 18 No. 2, pp. 277-311.

Desai, H., Krishnamurthy, S. and Venkataraman, K. (2006), "Do short sellers target firms with poor earnings quality? Evidence from earnings restatements", Review of Accounting Studies, Vol. 11 No. 1, pp. 71-90.

Diether, K.B., Lee, K.H. and Werner, I.M. (2009), "Short-sale strategies and return predictability", Review of Financial Studies, Vol. 22 No. 2, pp. 575-607.

Dvoř́a, T. (2005), "Do domestic investors have an information advantage? Evidence from Indonesia", The Journal of Finance, Vol. 60 No. 2, pp. 817-839.

Engelberg, J.E., Reed, A.V. and Ringgenberg, M.C. (2012), "How are shorts informed? Short sellers, news, and information processing", Journal of Financial Economics, Vol. 105 No. 2, pp. 260-278.

Fama, E.F. and MacBeth, J.D. (1973), "Risk, return, and equilibrium: empirical tests", Journal of Political Economy, Vol. 81 No. 3, pp. 607-636.

Froot, K.A. and Ramadorai, T. (2008), "Institutional portfolio flows and international investments", Review of Financial Studies, Vol. 21 No. 2, pp. 937-971.

Froot, K.A., O'connell, P.G. and Seasholes, M.S. (2001), "The portfolio flows of international investors", Journal of Financial Economics, Vol. 59 No. 2, pp. 151-193.

Green, T.C. and Hwang, B.H. (2012), "Initial public offerings as lotteries: skewness preference and firstday returns”, Management Science, Vol. 58 No. 2, pp. 432-444.

Griffin, J.M., Nardari, F. and Stulz, R.M. (2007), "Do investors trade more when stocks have performed well? Evidence from 46 countries”, Review of Financial Studies, Vol. 20 No. 3, pp. 905-951.

Grinblatt, M. and Keloharju, M. (2000), "The investment behavior and performance of various investor types: a study of finland's unique data set", Journal of Financial Economics, Vol. 55 No. 1, pp. $43-67$.

Harvey, C.R. and Siddique, A. (2000), "Conditional skewness in asset pricing tests", The Journal of Finance, Vol. 55 No. 3, pp. 1263-1295.

Kahneman, D. and Tversky, A. (1979), "Prospect theory: an analysis of decision under risk", Econometrica, Vol. 47 No. 2, pp. 263-291.

Morck, R., Shleifer, A. and Vishny, R.W. (1990), "Do managerial objectives drive bad acquisitions?”, The Journal of Finance, Vol. 45 No. 1, pp. 31-48.

Newey, W.K. and West, K.D. (1987), "Hypothesis testing with efficient method of moments estimation", International Economic Review, Vol. 28 No. 3, pp.777-787.

Seasholes, M.S. (2004), "Re-examining information asymmetries in emerging stock markets", Unpublished Working Paper, University of CA, Berkeley, CA.

Wang, S.F. and Lee, K.H. (2015), "Do foreign short-sellers predict stock returns? Evidence from daily short-selling in Korean stock market", Pacific-Basin Finance Journal, Vol. 32, pp. 56-75.

Wang, S.F., Lee, K.H. and Woo, M.C. (2017), "Do individual short-sellers make money? Evidence from", Journal of Banking and Finance, Vol. 79, pp. 159-172.

Zhang, X.J. (2013), "Book-to-market ratio and skewness of stock returns", The Accounting Review, Vol. 88 No. 6, pp. 2213-2240. 
JDQS

28,2

76

\section{Further reading}

Banerjee, S. and Graveline, J.J. (2013), "The cost of short-selling liquid securities", The Journal of Finance, Vol. 68 No. 2, pp. 637-664.

Chang, X., Chen, Y. and Zolotoy, L. (2017), "Stock liquidity and stock price crash risk", Journal of Financial and Quantitative Analysis, Vol. 52 No. 4, pp. 1605-1637.

Khan, M. and Lu, H. (2013), "Do short sellers front-run insider sales?", The Accounting Review, Vol. 88 No. 5, pp. 1743-1768.

Corresponding author

Shu-Feng Wang can be contacted at: sfwang@ajou.ac.kr

For instructions on how to order reprints of this article, please visit our website: www.emeraldgrouppublishing.com/licensing/reprints.htm

Or contact us for further details: permissions@emeraldinsight.com 